\title{
Konsekuensi Yuridis Kemajemukan Bangsa Indonesia Terhadap Pembangunan Hukum Nasional
}

\author{
Pandu Runtoko \\ Magister Hukum Fakultas Hukum Universitas Islam Indonesia Yogyakarta Indonesia \\ Jln. Cik Di Tiro No. 1 Yogyakarta Indonesia \\ panduruntoko88@gmail.com
}

\begin{abstract}
Indonesia is a country that upholds a high level of pluralism that spreads in every region. This study examines formulation of two problems: first, what are the factors that cause the plurality of society in Indonesia? Second, how does the plurality of society affect the development of law in Indonesia? This research was conducted with normative juridical method. This study concludes that first, the factors that cause the plurality of Indonesian society include cultural pluralism, ethnicity, customs, geographical conditions, religion, colonization of foreign nations. Second, the organizational principles of society and the principles that arise influence each other's evolutionary processes in the social and moral fields in society.
\end{abstract}

Key Words: Pancasila; national pluralism; reflective law

\begin{abstract}
Abstrak
Indonesia merupakan suatu negara yang mempunyai tingkat kemajemukan tinggi/pluralisme yang menyebar pada setiap daerah. Penelitian ini mengkaji dua rumusan masalah, pertama, apa faktorfaktor yang menyebabkan kemajemukan masyarakat di Indonesia? Kedua, bagaimana pengaruh kemajemukan masyarakat bagi pembangunan hukum di Indonesia? Penelitian dengan metode yuridis normatif. Penelitian ini menyimpulkan, pertama, faktor yang menyebabkan kemajemukan masyarakat Indonesia antara lain kemajemukan kebudayaan, suku bangsa, adat istiadat, kondisi geografis, agama, penjajahan bangsa asing. Kedua, prinsip-prinsip organisasional masyarakat dan prinsipprinsip yang timbul saling mempengaruhi proses-proses evolusioner di bidang sosial dan moral dalam masyarakat.
\end{abstract}

Kata-kata Kunci: Pancasila; kemajemukan bangsa; hukum refleksif 


\section{Pendahuluan}

Indonesia merupakan negara yang mempunyai kebudayaan yang beraneka ragam, yang tersebar dari Sabang sampai Merauke. Banyak sekali budaya, suku bangsa, adat istiadat serta tatanan kehidupan masyarakat yang hidup didalamnya. Setiap daerah yang ada di Indonesia memilliki keanekaragaaman budaya yang berbeda-beda. Meski banyak sekali perbedaan yang ada di dalam kehidupan bangsa Indonesia ini, hal itu tetap mempunyai suatu tujuan bersama yaitu menciptakan kehidupan bangsa yang adil, makmur, sentosa dan sesuai dengan Pancasila. Seperti tercermin juga pada slogan "Bhinneka Tunggal Ika" yang berarti meskipun berbeda-beda tetapi tetap satu jua. Hal itu mencerminkan bagaimana perbedaan budaya dan suku bangsa yang ada di Indonesia.

Masyarakat Indonesia secara demografis maupun sosiologis merupakan wujud dari bangsa yang majemuk. Ciri yang menandai sifat kemajemukan ini adalah adanya keragaman budaya yang terlihat dari perbedaan bahasa, sukubangsa (etnis) dan keyakinan agama serta kebiasaan-kebiasaan kultural lainnya. Pada satu sisi, kemajemukan budaya ini merupakan kekayaan bangsa yang sangat bernilai, namun pada sisi yang lain keragaman kultural memiliki potensi bagi terjadinya disintegrasi atau perpecahan bangsa. Pluralitas budaya ini seringkali dijadikan alat untuk memicu munculnya konflik suku bangsa, agama, ras dan antargolongan (SARA), meskipun sebenarnya faktor-faktor penyebab dari pertikaian tersebut lebih pada persoalan-persoalan politik, ketidakadilan sosial dan ketimpangan ekonomi. Uni Soviet dan Yugoslavia bisa menjadi cermin untuk memahami kegagalan suatu negara dalam mengelola perbedaan kultural.

Secara konseptual, potensi konflik yang besar dalam masyarakat Indonesia yang majemuk ini disebabkan oleh terbelahnya masyarakat ke dalam kelompokkelompok berdasarkan identitas kultural mereka. Identitas kultural sebagai perasaan (emotional significance) dari individu-individu untuk ikut memiliki (sense of belonging) atau berafiliasi dengan kultur tertentu. Masyarakat yang terbelah ke dalam kelompok-kelompok itu kemudian melakukan identifikasi kultural, yaitu menegaskan diri mereka sebagai representasi dari sebuah budaya partikular. Identifikasi kultural ini pada gilirannya akan menentukan mereka ke dalam ingroup atau outgroup. Bagaimana setiap individu berperilaku, sebagian ditentukan oleh apakah mereka termasuk ke dalam kelompok budaya tertentu atau tidak.

Di dalam sosiologi dikenal istilah crosscutting cleavage, yaitu masyarakat yang terkonsentrasi secara eksklusif berdasarkan identitas kulturalnya. Crosscutting cleavage ini memudahkan terjadinya penggalangan massa ketika terjadi konflik yang melibatkan anggota-anggota dari kelompok kultural yang 
berbeda. Di negeri ini, banyak permukiman warga berdasarkan identitas kelompok kulturalnya masing-masing, misalnya Pecinan, Kampung Arab, Kampung Bali, Kampung Bugis, dan lain-lain. Pada satu sisi, permukiman yang terpusat secara kultural ini akan menciptakan rasa aman sekaligus nyaman bagi para penghuninya, namun pada sisi yang lain, lingkungan permukiman tersebut akan menjadi kontra produktif ketika dihadapkan dengan karakteristik masyarakat Indonesia yang majemuk. ${ }^{1}$

Perbedaan budaya dan suku bangsa berarti perbedaan pula berbagai tatanan kehidupan, adat istiadat, dan juga norma-norma hukum yang ada didalamnya. Daerah Istimewa Yogyakarta merupakan kota yang memiliki keistimewaan di banding kota-kota yang lain yang berada di Negara Indonesia ini. Salah satu bentuk keistimewaan yang dimiliki kota Yogyakarta yaitu pada Pemilihan Gubernur dipilih melalui penetapan, yang dalam hal ini Gubernur Daerah Istimewa Yogyakarta ialah Seorang Raja dari Kasultanan Kraton Ngayogyakarta. ${ }^{2}$

Negara Indonesia ini merupakan suatu negara yang mempunyai tingkat kemajemukan tinggi/pluralisme yang menyebar pada setiap daerah. Hal itu di buktikan dengan banyaknya budaya yang tersebar di berbagai daerah. Kita tidak pernah bisa memungkiri keadaan Bangsa Indonesia yang beraneka ragam ini membawa banyak sekali konsekuensi yang ada. Salah satunya yaitu berupa konsekuensi yuridis kemajemukan bangsa Indonesia terhadap pembangunan hukum nasional.

\section{Rumusan Masalah}

Berdasarkan uraian di atas, maka rumusan masalah yang akan dikaji dalam penelitian ini ialah: pertama, apa faktor-faktor yang menyebabkan kemajemukan masyarakat di Indonesia? Kedua, bagaimana pengaruh kemajemukan masyarakat bagi pembangunan Hukum di Indonesia?

\section{Tujuan Penelitian}

Penelitian ini bertujuan untuk: pertama, mengkaji dan menganalisis konsekuensi yuridis akibat hukum dari kemajemukanbangsa indonesia terhadap pembangunan hukum nasional untuk mengetahui pengaruh dari aturan hukum yang telah diatur dalam sistem hukum nasional, terhadap kemajukan bangsa Indonesia, mengingat bangsa indonesia memiliki keberagaman budaya di setiap daerahnya.

1 Turnomo Rahardjo, "Memahami Kemajemukan Masyarakat Indonesia (Perspektif Komunikasi Antarbudaya)", Tesis, Fakultas Hukum Universitas Diponegoro, Semarang, 2010.

2 SKH Kedaulatan Rakyat, 10 Agustus 2011, hlm 2 


\section{Metode Penelitian}

Jenis penelitian normatif, penelitian hukum normatif adalah penelitian hukum yang meletakkan hukum sebagai sebuah bangunan sistem norma. Sistem norma yang dimaksud adalah mengenai asas-asas, norma, kaidah dari peraturan perundang-undangan, putusan pengadilan, perjanjian serta doktrin (ajaran). ${ }^{3}$ Pendekatan penelitian yang digunakan adalah metode pendekatan historis (historical approach) dengan tujuan untuk mengungkap materi sejarah yang mempunyai relevansi pada masa sekaranh untuk menemukan asas atau doktrin hukum yang dapat menjawab permaslahan hukum pada masa. ${ }^{4}$ Selain itu menggunakan pendekatan Konseptual (conceptual approach), pendekatan ini dilakukan manakala peneliti tidak beranjak dari aturan hukum yang ada karena belum adanya aturan hukum untuk masalah yang dihadapi. ${ }^{5}$

\section{Hasil Penelitian dan Pembahasan}

\section{Faktor-Faktor Yang Mempengaruhi Kemajemukan Masyarakat di Indonesia}

Ketika kita berbicara kemajemukan maka yang akan terlintas dipikiran kita ialah adanya berbagai macam kebudayaan, suku bangsa, agama, adat istiadat yang hidup di dalamnya. Itu tidaklah salah karena dari situlah kemajemukan itu bermuala, apabila suatu negara atau bangsa itu hanya berisikan satu suku bangsa, satu budaya, satu agama, satu adat sitiadat maka bangsa itu bukanlah suatu bangsa yang majemuk atau plural, melainkan suatu bangsa yang monoisme. Tapi dewasa ini jarang sekali ditemui Bangsa yang monoisme, bahkan bisa dibilang hampir semua bangsa yang ada di dunia ini merupakan bangsa yang majemuk ataun plural. Namun tingkat kemajemukan atau pluralisme antar bangsa itu berbeda-beda. Ada yang mempunyai tingkat kemajemukan yang besar (Indonesia, Perancis, Inggris, dll) namun ada juga yang tingkat kemajemukannya kecil (Israel, Palestina, Arab Saudi, dll). Adanya kemajemukan tersebut tentunya mempunyai faktor-faktor penyebabnya. ${ }^{6}$

Indonesia merupakan Negara Kepualauan yang beraneka ragam budayanya yang tersebar di 34 provinsi. Setiap provinsi di Indonesia memiliki corak kebudayaan, suku bangsa, adat istiadat yang berbeda- beda. Apa yang menjadi kebudayaan, adat istiadat, suku bangsa itu dapat menjadi cerminan atau

\footnotetext{
${ }^{3}$ Mukti Fajar \& Yulianto Achmad, Dualisme Penelitian Hukum Normatif \& Empiris, Pustaka Pelajar, Yogyakarta, 2013, hlm. 34. 86.

4 Bambang Sunggono, Metode Penelitian Hukum, Cetakan ke 14, PT Grafindo Persada, Jakarta, 2013, hlm.

5 Peter Mahmud Marzuki, Penelitian Hukum, Edisi Revisi, Kencana, Jakarta, 2011, hlm.177.

6 https://www.slideshare.net/LestariMoerdijat/kemajemukan-masyarakat-indonesia, $\quad$ diakses 02 November 2020, Pukul 01.00 WIB
} 
gambaran terhadap tingkah laku dan tatanan kehidupan suatu masyrakat tertentu. Atau dengan bahasa ringannya bahwa adat istiadat, kebudayaan, suku bangsa itu mencerminkan diri, jiwa dan tingkah laku suatu masyarakat tersebut. ${ }^{7}$

Sebagai gambaran, banyak yang bilang kalo masyarakat kota Yogyakarta itu sopan, halus, lemah lembut, dsb. Hal ini sesuai dengan apa yang menjadi ciri dan budaya jawa, dimana di dalam masyarakat Jawa dikenal yang namanya "Unggah Ungguh / Tata Krama" yang berarti sopan santun. Dengan adanya pemahamam akan kebudayaan jawa tersebut, secara tidak langsung berpengaruh terhadap tingkah laku masyarakat kota Yogyakarta. ${ }^{8}$

Berbagai faktor yang menyebabkan tingkat kemajemukan yang tinggi di Indonesia ialah di karenakan:

1) Kebudayaan

Bangsa Indonesia merupakan Bangsa yang memiliki banyak sekali kebudayaan yang ada dan hidup di dalamnya, kebudayaan Bangsa Indonesia hidup dan tumbuh di dalam jiwa-jiwa setiap tingkatan kehidupan masyarakat. Dimana setiap kebudayaan itu memiliki tatanan kehidupan, adat istiadat maupun norma-norma yang hidup didalamnya. Macammacam kebudyaan ini tersebar luas diseluruh wilayah Nusantara. Kita sudah mempelajari keragaman suku bangsa di Indonesia. Tiap suku bangsa memiliki adat istiadat dan budaya sendiri. Budaya dan adat istiadat daerah dapat kita jumpai dalam hidup sehari-hari. Maka terbentuklah bermacammacam adat istiadat dan budaya sendiri. ${ }^{9}$

2) Geografi

Keadaan geografis Indonesia yang terdiri dari lebih 17.580 pulau-pulau besar dan kecil yang tersebar di sepanjang equator lebih kurang 3000 mil dari barat ke timur, dan lebih dari 1000 mil dari utara ke selatan. Indonesia terletak di antara dua samudra yaitu samudra Hindia dan samudra pasifik. Oleh karena itu, letaknya berada di tengah-tengah lalu lintas perdagangan laut antara benua Asia dan benua Australia. Iklim yang berbeda-beda serta struktur yang tidak sama antara berbagai daerah di kepulauan nusantara ini menyebabkan terjadinya perbedaan curah hujan dan kesuburan tanahnya. Menetap di tempat yang berbeda dan terpisah-pisah.

Kehidupan mereka di tiap-tiap daerah sangat bergantung kepada keadaan dan potensi alam lingkungannya. Keadaan Geografi Negara Indonesia yang kepulauan ini, bahkan disebut sebagai Negara Kepualauan karena banyaknya pulau-pula yang dimiliki Bangsa Indonesia ini. Hal ini jelaslah berpengaruh trerhadap kemajemukan budaya yang ada. Tingkat kehidupan yang berada di wilayah Pulau Jawa dengan Pulau Sumatra pasti berbeda, bisa dari segi budaya, makanan, pola kehidupan dll. Begitu juga antara

${ }^{7}$ https://indomaritim.id/keberagaman-dalam-masyarakat-indonesia/, diakses 02 November 2020. Pukul 01.30 WIB.

${ }^{8}$ Majalah Kabare Jogja, edisi september 2014, hlm. 12

${ }^{9}$ www.google.com , Artikel 20 Februari 2010, Kemajemukan Masyarakat Indonesia, 07 Maret 2018, Pukul $02.21 \mathrm{WIB}$ 
Pulau Papua dengan Pulau Kalimantan dan Pulau Sulawesi pasti sangat berbeda pula seluruh tartan kehidupan yang ada. Misal apabila di jawa makanan pokoknya ialah beras, namun untuk penduduk Indonesia bagian Timur (Maluku, Papua dsb) makanan pokoknya ialah Sagu. ${ }^{10}$

3) Agama

Pengaruh agama dan kebudayaan islam yang dibawa oleh pedagang dari gujarat dan persia sekitar abad ke-13 penyebarannya sangat cepat dan meluas terutama dikawasan pantai indonesia. Sampai sekarang di daerah aceh masih kental nilai-nilai ajaran islam tertanam di masyarakatnya terbukti dengan adanya gerakan aceh merdeka yang menginkan adanya negara baru yang berdasarkan ajaran islam. Kedatangan bangsa barat ke indonesia mulai dari jalur perdagangan, kolonialisasi, penjajahan dan misimisi keagamaan. Semua jalur tersebut mempengaruhi dan memperkomplek struktur dan pengelompokan masyarakat Indonesia mulai dari cara memperkenalkan unsur-unsur kebudayaan barat beserta nilai-nilai agama nasraninya, maupun dengan memodifikasi unsur-unsur yang telah ada di masyarakat Indonesia itu sendiri. ${ }^{11}$

4) Penjajahan Bangsa Barat

Tidak bisa di pungkiri bahwa Negara Indonesia sudah banyak tercampur dengan kebudayaan asing, hal ini tidak terlepas bahwa negara Indonesia telah banyak sekali mengalami penjajahan, dari bangsa Portugis, Inggris, Belanda hingga Jepang. Akan banyaknya hal-hal tersebut membawa banyak sekali percampuran kemajemukan yang ada didalam Indonesia.

\section{Pengaruh Kemajemukan Masyarakat bagi Pembangunan Hukum Nasional}

Tidak bisa dipungkiri bahwa banyaknya kebudayaan yang ada dan hidup berkembang didalam masyarakat Indonesia secara tidak langsung mempengaruhi hukum adat yang tinggal dan hidup didalam masyarakat tersebut. Selain itu faktor geografis Indonesia yang tersebar dalam berbagai pulau juga sangat mempengaruhi adat istiadat antar suku dan budaya yang ada. Hal ini membuat keberadaan masyarakat adat di Indonesia beraneka ragam dengan tatanan kehidupan yang berbeda-beda antara suatu daerah dengan daerah lainnya. Dan hukum adat yang ada tersebut berpengaruh terhadap pembangunan hukum nasional.

Hingga saat ini masih banyak orang yang beranggapan, bahwa Hukum Adat itu adalah hukum peninggalan masa lalu. Ia selalu berorientasi ke masa lampau dan kurang cocok dengan kehidupan modern masa kini. Pendapat tersebut walaupun tidak sepenuhnya salah, tetapi tidak dapat kita terima sepenuhnya dalam rangka menilai bagaimana berlakunya Hukum Adat dimasa

\footnotetext{
10 https://www.kompasiana.com/elinrachma/5847c4f151f9fd1a0f70dcd6/faktor-penyebab-kemajemukan-diindonesia?page=all , Artikel, Faktor Penyebab Kemajemukan Indonesia, 02 November 2020, Pukul 02.26

${ }^{11}$ Febrinialdi’s Blog, Analisa Kemajemukan Masyarakat Indonesia, 02 November 2020, Pukul 03.00 WIB
} 
kini, sekalipun Hukum Adat itu bersifat tradisional yang berarti sangat terikat pada tradisi-tradisi lama yang diwariskan oleh nenek moyang kita, namun kita tidak boleh secara tergesa- gesa menarik kesimpulan bahwa Hukum Adat itupun pantang berubah.

Memang terlihat sedikit agak ironis, kalau dikatakan Hukum Adat itu bersifat tradisional dan sekaligus selalu berubah-ubah, karena antara "tradisi dan perubahan" pada umumnya selalu ditempatkan orang pada dua kutub yang saling bertolak belakang. Tradisi selalu menghendaki kelanggenggan secara apa adanya, diteruskan menurut apa yang pernah berlaku "dahulu" tanpa perubahan, sedangkan sebaliknya perubahan tidak menghendaki secara turun temurun itu-itu juga, akan tetapi dalam setiap waktu, atau setidak-tidaknya dalam waktu yang relatif singkat semuanya harus dirubah dan dibaharui menuju kepada pihak yang lebih baik.

Terhadap pihak yang menyatakan bahwa Hukum Adat itu selalu berorientasi kepada masa lampau sebagaimana yang diungkapakan di atas, Soerjono Soekanto kurang sependapat. Bahwa orientasi Hukum Adat pada masa lampau tidak seluruhnya benar, karena menurut pendapatnya orientasi pada masa lampau dan masa depan merupakan titik batas. Proses orientasi biasanya bergerak antara kedua batas tadi, kadang-kadang bergerak ke masa lampau kadang bergerak ke masa depan ${ }^{12}$. Karena itu sulitlah untuk menyatakan bahwa Hukum Adat itu selalu berjalan ketinggalan di belakang perubahan dan modernmisasi yang sekarang tengah berlangsung. Hal tersebut tidaklah berarti kita harus mempertahankan secara sepenuhnya Hukum Adat sebagaimana yang telah kita ketahui dimasa lampau.

Hal demikian mengandung banyak bahaya sebagaimana diungkapkan oleh Soerjono Soekanto:

"Apabila Hukum Adat dipertahankan seutuhnya, mungkin akan timbul kecenderungan yang kuat untuk mempertahankan unsur tradisional dalam bentuk aslinya (conserveren), tanpa memilih manakah diantara unsur-unsur itu yang mempunyai pengaruh positif dan negative terhadap modernisasi. Hal semacam ini mungkin mengakibatkan terjadinya politik untuk menjauhkan atau menutup masyarakat tradisional dari dan terhadap proses modernisasi yang mungkin datang dari masyarakat lain".

Karena itu apabila menunjuk bahwa sesuatu itu adalah Hukum Adat, sifatnya perubahan dan perkembangan haruslah diperhatikan, jadi bukan hanya Hukum Adat saja sebagaimana yang diketahui pada masa-masa lampau. Dapatnya Hukum Adat beradaptasi dengan perubahan dan mengikuti proses

${ }^{12}$ Soerjono Soekanto, Kedudukan dan Peranan Hukum Adat Di Indonesia, Kurnia Esa, Jakarta, 1982, hlm. 85 
modernisasi adalah disebabkan oleh karena sifatnya melekat didalam Hukum Adat itu sendiri. Hukum Adat disamping sifatnya yang tradisional juga mempunyai corak "dapat berubah" dan "mempunyai kesanggupan untuk menyesuaikan diri". ${ }^{13}$ Sedang menurut istilah Djojodigoeno Hukum Adat itu mempunyai siifat "dinamik" dan "plastis". ${ }^{14}$

Hukum Adat bersifat hidup dinamis karena ia dapat mengikuti perkembangan masyarakat yang pasti membutuhkan perubahan dalam dasar-dasar hukum sepanjangjalannya sejarah. Hukum bersifat plastich bilamana dalam pelaksanaannya dapat diperhatikan hal-hal yang tersendiri. Sifat plastis ini dapat juga disebut sebagai sifat kelenturan seperti sebuah rotan yang dilentur ke kiri atau ke kanan sesuai dengan kebutuhan dan kemauan kita. Dengan adanya lenturan inilah Hukum Adat menyesuaikan diri dengan situasi dan kondisi yang berkembang.

Dewasa ini perkembangan Hukum Adat tidaklah stagnan atau berhenti namun Hukum Adat senantiasa berkembang mengikuti zaman dan turut serta berpengaruh dalam setiap penciptaan Hukum-Hukum Nasional. Tidak bisa dipungkiri bahwa untuk membuat suatu Peraturan, terutama Peraturan Peraturan yang diciptakan dalam ruang lingkup kedaerahan (misal Perda, UU Otoda, dll.) maka haruslah disesuikan dengan tatanan kehidupan masyarakat yang ada, karena apabila hal tersebut tidak dilakukan niscaya penerapan hukum tersebut tidak akan dapat terlaksana dengan baik, dalam artian tingkat pemahaman masyarakat tersebut tidak dapat diresapi dengan baik. Dan bahkan akan banyak terjadi pertentangan karena tidak sesuai dengan tatanan kehidupan, kebudayaan adat istiadat maupun kondisi lingkungan yang ada.

Mengenai perkembangan baru yang terjadi dalam Hukum Adat kita, adalah sangat tepat sekali apa yang telah dilukiskan oleh Koesno, bahwa perkembangan itu adalah mencakup pengertian daripada Hukum Adat, Kedudukan Hukum Adat, isi dan lingkungan kuasa atas orang dan ruang. Kiranya dapat diikuti kesimpulan yang telah dibuatnya berkenaan dengan hal tersebut sebagai berikut:

“Mengenai pengertian: perkembangan bermula, dari adat yang mempunyai sanksi, kemudian berkembang menjadi segala keputusan-keputusan yang diambil oleh penguasa adat dalam lingkungan masyarakatnya dalam hubungannya dengan ikatan strukturalmasyarakatnya. Setelah itu Hukum Adat dilihat sebagai hukum yang lahir langsung dari pikirean dan cita-cita serta kebutuhan hukum rakyat Indonesia, pengertian mana akhirnya menjadi hukum yang lahir dari kepribadian bangsa Indonesia, singkatnya hukum asli bangsa kita atau hukum asli Indonesia. Perkembangan ini dalam kenyataannya tidak banyak disadari dan diketahui oleh para sarjana hukum kita".

${ }^{13}$ Van Dijk, R. Pengantar Hukum Adat Indonesia, Sumur, Bandung, 1964, hlm. 7

${ }^{14}$ Djojodigoeno, Asas-Asas Hukum Adat, Yayasan Badan Penerbit Gajah Mada, Yogyakarta 1958, hlm. 7 
Kedudukan Hukum Adat ditunjukkan bahwa perkembangannya bermula sebagai suatu Hukum Golongan, yakni dari golongan Bangsa Indonesia asli dan dalam hal-hal tertentu juga golongan timur asing bukan Cina. Sebagai demikian Hukum Adat terlihat sangat beraneka ragam dan banyak sekali karena suku dan golongan rakyat Indonesia asli sangat banyak. Dari kedudukannya sebagai hukum golongan kemudian meningkat sebagai hukum yang membawa bentuknya semangat kebangsaa, untuk kemudian menjadi dasar Hukum Nasioanl kita. Terhadap hal terakhir ini dapat diberikan catatan bahwa kedudukannya sebagai demikian sejak 1950 sampai 1959 goyah dan dikembalikan lagi sebagai bagian Hukum Nasional yang kurang penting untuk digeser oleh Hukum Kodifikasi ala Barat. Pada 1959 sampai dewasa ini, di bawah naungan Undang-Undang Dasar 1945, kedudukannya tersebut dikembalikan tetapi dalam 1966 sebutannya diganti dengan Pancasila, atau tegasnya Hukum Pancasila. Tentang kedudukan hukum Adat yang demikian inipun tidak semua Srjana Hukum sependapat.

Isi dan lingkungan kuasanya atas orang dan ruang, perkembangan yang dapat dicatat ialah pada mulanya diisi dengan taraf ilmu pengetahuan sesuai dengan waktunya, dengan ketentuan-ketentuan yang letaknya pada taraf kebiasaan-kebiasaan dari golongan atau suku-suku yang ada. Dari sini kemudian ditarik labih jauh lagi yakni kepada asas-asas yang terakhir mulai diarahkan kepada nilai-nilai hukum yang hidup di dalam masyarakat. Semakin abstrak pengisiannya semakin luas daya mencakup lingkungan kuasa atas orang dan ruangnya sehingga akhirnya dapat berlaku Nasional. ${ }^{15}$ Betapa berpengaruhnya keanekaragaman budaya dan geografi auat lingkungan bangsa Indonesia terhadap perkembangan Hukum Nasional.

Kita tahu bahwa negara Indonesia mayoritas penduduknya beragama Islam, dengan adanya kenyataan tersebut tidaklah salah apabila dalam pembentukkan hukum maupun penciptaan hukum yang ada di Indonesia ini tidak jauh-jauh korelasinya bagi umat muslim. Dan bisa juga dikatakan dalam pembuatan hukum tersebut senantiasa berpatokan pada ajaran Agama Islam, hal ini bisa dimaklumi karena banyak orang-orang hukum maupun orang yang berwenang membuat aturan itu memeluk Agama Islam. Dengan berpijak pada teras kehidupan religi umat Islam dari masa ke masa terutama masa kelhirannya, akan diperolah suatu gambaran kehidupan social cultural pada masyarakat muslim bahwa dengan hukum agamanya mereka dapat ditasbihkan bagai sepasang mata koin yang tidak bisa terpisahkan. Hukum Islam bagi penganutnya tidak hanya

15 Moh. Koesno, Perkembangan Hukum Adat Setelah Perang Dunia II Dalam rangka Pembaharuan hukum Nasional, Dalam BPHN, Simposium Sejarah hokum, Binacipta, Bandung, 1976, hlm. 115-116. 
merupakan sumber hukum dari segala hukum, namun juga tidak diragukan nilai keadilan dan kebenarannya sehingga pada akhirnya dianggap sebagai hukum tertinggi dari segala hukum yang ada.

Pandangan tersebut dipantulkan oleh nur pondasi iman bahwa hukum Islam bersumber dari Wahyu Illahi, bukan bersumber dari olahan akal manusia. Sebab bagaimanapun tidak bisa disangkal bahwa hukum yang dibentuk sebagai hasil rasio manusia seringkali berbenturan antara yang satu dengan yang lainnya. Sepanjang sejarah perkembangan hukum, perdebatan hukum hasil olahan rasio manusia tidak pernah berakhir, sementara hukum yang berasal dari Tuhan tidak dapat dicemari oleh suatu pergeseran nilai, senantiasa sesuai dengan perkembangan peradaban manusia dalam berbagai ruang dan waktu. Oleh karena itu, sejalan dengan ditaatinya hukum Islam oleh penganutnya, pada dasarnya secara historis proses pemecahan masalah umat Islam yang merujuk kepada ketentuan hukum Islam secara faktual telah berjalan di Indonesia sejak tersiarnya agama Islam di Indonesia.

Hal tersebut antara lain karena diimperatifkan oleh syariat Islam yang sarat tertuang dalam Al-Quran dan As-Sunnah agar umat Islam harus berpijak pada hukum yang ditetapkan oleh Allah SWT dibarengi ancaman bagi yang keluar dari Hukum Allah akan mendapat sebutan sebagai orang kafir, fasik, zalim dan sebagainya sebutan yang sangat tercela. Pada sisi lain juga juga ditemukan syariat Islam yang menyatakan bahwa jika ada tiga orang muslim, kemudian dua diantaranya berselisih, maka yang ketiga haruslah tampil menjadi hakim bagi mereka. Oleh karena itulah jika diantara orang Islam terjadi perselisihan, pada umumnya mereka mengadukan perselisihan itu kepada orang yang dianggap dapat memcahkan persoalan dengan landasan hukum agama yaitu para alim ulama atau sesepuh agama.

Diilhami oleh kenyataan sosial kultural masyarakat muslim seperti itulah, maka pada masa kolonial Belanda dulu dikenal atau berkembang suatu teori yang dikenal dengan "Theori Receptie in Complexu" yang disponsori oleh Van Den Berg yang intinya mengandung suatu rumusan bahwa hukum yang berlaku bagi orang Indonesia asli adalah Undang - Undang Agama mereka (goosdientige wetten). Teori tersebut sejak 1855 telah memeperoleh landasan perundangundangan Hindia Belanda melalui Stbld. 1855 No. 2. Pada perkembangan berikutnya, teori ini mendapat tantangan dari ahli hukum Belanda yang bertugas ganda selaku Oreantalis yaitu Christian Snouck Hurgronje. Menurut beliau, hukum Islam dapat diterapkan selama hukum tersebut telah meresap pada hukum adat, dengan arti lain, hukum Islam dapat dianggap suatu hukum jika tidak bertentangan dengan hukum adat. Teori Resepsi ini dikaitkan dengan 
lembaga peradilan Islam yang dirumuskan pada Pasal 134 ayat (2) IS (Indische Staatsregeling) yang menyatakan bahwa:

"Dalam hal terjadi perkara perdata antara sesame orang Islam akan diselesaikan oleh hakim agama Islam apabila keadaan tersebut telah diterima oleh hukum adat mereka dan sejauh tidak ditentukan oleh ordonansi".

Dengan adanya teori ini, maka Hukum Islam tidak lagi mendapat tempat tertinggi dan dapat dinyatakan bahwa teori resepsi berusaha menghentikan perkembangan eksistensi hukum Islam. Oleh karena itu, tepatlah jika seorang ahli hukum Islam, Hazairin menyatakan bahwa, teori resepsi merupaka teori iblis, sebab teori tersebut berintikan menjauhkan umat Islam dari hukum agamanya sendiri.

Dewasa ini perkembangan hukum di Indonesia banyak diilhami oleh faktor agama, yang dalam hal ini Faktor Agama Islam mempunya pengaruh dalam pembantukan suatu Peraturan, sebagai contoh yaitu penerapan Hukum Syariat Islam di Aceh, meski belum secara luas namun secara tidak langsung hal itu menggambarkan betapa ruang lingkup agama memiliki peranan yang fundamental dalam pembangunan HukumNasioanal ${ }^{16}$.

Pembangunan Hukum Nasioanl tidak dapat dipisahkan dari perjalanan sejarah perkembangan tatanan yang berlaku pada masyarakat Indonesia. Hal ini disebabkan karena pembentukan suatu tatanan hukum sangat dipengaruhi perkembangan masyarakat, budaya dan faktor yang lainnya. Selain itu dalam konteks yang lebih luas pembentukan tatanan hukum juga dipengaruhi oleh aliran pemikiran yang berkembang pada suatu tempat dan amsa tertentu.

Sebagaimana yang diketahui bahwa sebelum masa penjajahan perkembangan tatanan hukum di Indonesia berjalan dengan wajar mengikuti perkembangan sebagaiman yang dialami oleh negara-negara lain juga. Perjalanan Negara Indonesia yang sedang berjalan tiba-tiba terpotong dengan masuknya penjajah Bangsa barat selama kurang lebih 350 tahun lamanya, dari bangsa Portugis, Inggris, Belanda hingga Jepang. Pada masa itu perkembangan hukum Indonesia mengalami masa-masa kegelapan atau kesuraman dengan terdesaknya hukum-hukum asli Indonesia yang secara paksa di gantikan dengan sistem hukum asing (Hukum Eropa) dan dibiarkannya terjadinya dualism yang mengambang sepanjang masa penjajahan. Pada masa ini pula, terjadi semacam politik pembodohan dengan tertutupnya pandangan masyarakat Indonesia terhadap perkembangan yang terjadi di dunia luar atau negara-negara lainnya.

${ }^{16}$ Ropaun Rambe \& A. Mukri Agafi, Implementasi Hukum Islam, PT Perca, Jakarta, 2001, hlm. 2. 
Hal ini menyebabkan tertutupnya kemungkinan penyesuaian tatanan hukum asli terhadap perkembangan dan tuntutan.

Hingga saat ini (lebih dari enam puluh lima tahun perencanaan tekad pembangunan hukum nasional), wajah hukum nasional kita tidak jauh berbeda dengan dengan hukum zaman kolonial, bahkan ada pendapat ekstrem yang mengatakan bahwa hukum Indonesia saat ini ialah hukum colonial yang "diberi baju" hukum nasional. Hal ini tidak hanya berlaku eks produk hukum kolonial yang telah dinasionalisasikan, namun juga nampak dalam produk-produk hukum nasional yang baru sekalipun.

Secara paradigmatik hal demikian bisa dikatakan bahwa belum ada proses pembebasan hukum asing dalam pembangunan hukum nasional Indonesia. Hal tersebut disamping karena keberadaan tatanan hukum asli masyarakat Indonesia yang hidup dan berkembang sejak dulu, yang kini diangkat dalam pembangunan Hukum Nasional (misalnya melalui kebijakan yang meningkatkan hukum adat sebagai basis hukum nasional), pengaruh tatanan hukum modern (Hukum Eropa) yang dibawa oleh penjajah tersebut, terutatama Belanda yang telah mengakar dan tertanam kuat dalam system Hukum Nasional (misalnya politik unifikasi dan

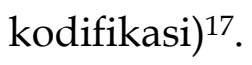

Pengaruh penjajahan Bangsa Asing masih begitu melekat pada Citra Pembangunan Hukum Nasioanal Indonesia, bnisa kita lihat contoh yang kita tahu bahwa KUHPerdata maupun KUHP yang kita gunakan merupakan Kitab Hukum peninggalan kolonial Belanda yang masih digunakan oleh masyarakat hukum Indonesia hingga saat ini.

Kemajemukan masyarakat yang ada di negara Indonesia ini akan sangat sulit jika kita hanya menggunakan sisi hukum positive saja, karena kemungkinan besar hukum tidak dapat masuk kedalam kehidupan masyarakat, padahal Krisis hukum terjadi karena ketidakmampuan hukum merespon kebutuhan adanya integrasi system dan juga adanya krisis legitimasi hukum, Dominasi negara sebagai pengatur di satu sisi dan meningkatkan kesejahteraan rakyat di sisi yang lain, menyebabkan lahirnya konsep negara kesejahteraan (welfare state) dan negara pengatur (regulatory state). Salah satu persoalan yang dialami oleh hukum modern dewasa ini adalah adanya "krisis" rasionalitas formal. Oleh karena itu, maka perlu dilakukan rematerialisasi hukum, Timbulnya rematerialisasi hukum karena adanya krisis rasionalitas formal pada hukum modern.

Bangsa Indonesia membutuhkan suatu tata hukum postmodern yang harus berorientasi pada proses self-refleksif dalam sub-subsistem yang berbeda. Selfrefleksif adalah proses yang memungkinkan hukum merefleksikan dirinya

${ }_{17}$ Al. Wisnubroto, Quo Vadis Tatanan Hukum Indonesia, Universitas Atmajaya, Yogyakarta, 2007, hlm. 3 
sendiri guna mengatasi persoalan dalam masyarakat. Hal ini bermaksud agar hukum tidak terisolasi dari lingkungannya, maka perlu dikembangkan logika institusional (institutional logic) yakni konsep yang membentuk sistem hukum agar tidak terisolasi dari lingkungannya, dengan cara pembentukan hukum yang didasarkan pada "self reference of legal structures" (struktur hukum yang menafsirkan diri sendiri dengan memperhatikan kebutuhan internal dan tuntutan eksternal).

Metode pengembangan hukum menurut Gunther Teubner dalam hukum refleksif menggabungkan konsep dinamika internal dari tata hukum maupun dampak dari struktur sosialyang sedang dalam perubahan, Kompleksitas yang secara sosial memadai (socially adequate complexity), bahwa tata hukum dalam masyarakat pastmodern mestinya memiliki mekanisme-mekanisme yang memungkinkan masyarakat melakukan aktivitasnya dalam suatu lingkungan yang kompleks, yang secara fungsional terdiferensiasi. Prinsip-prinsip organisasional masyarakat (organizational principles of society) dari Habermas yakni prinsip-prinsip yang timbul dari saling mempengaruhinya proses-proses evolusioner di bidang sosial dan moral dalam masyarakat.

Sebenarnya Indonesia sudah mempunyai suatu sistem yang mencakup untuk sebuah tatanan masyarakat Indonesia yang majemuk ini yaitu ideologi Pancasila dengan kebhinekaan tunggal ika nya, Pancasila (staatsfundamentalnorm) merupakan sumber dari segala sumber hukum, yang berarti bahwa segala bentuk hukum di Indonesia harus diukur menurut nilai-nilai yang terkandung dalam Pancasila, dan didalam aturan hukum itu harus tercermin kesadaran dan rasa keadilan yang sesuai dengan kepribadian dan falsafah hidup bangsa. Nilai-nilai Pancasila merupakan nilai-nilai yang mencerminkan atau menggambarkan keanekaragaman budaya, suku, bahasa, daerah dari suatu kemajemukan bangsa Indonesia, yang oleh negara melalui aparatur pemerintah mengatur sistem nilainilai dasar tersebut menjadi suatu norma/hukum yang mengatur kehidupan masyarakat bangsa indonesia sendiri, yang tidak berakar secara utuh pada salah satu budaya masyarakat etnik atau tradisi keagamaan melainkan berakar pada semua sistem budaya yang ada.

Konsekuensi yuridis dari kemajemukan bangsa indonesia, ${ }^{18}$ hanya saja mungkin saat ini penerapanya belum dapat dilaksanakan secara maksimal, mungkin di karenakan beberapa hal, menurut saya Pancasila ini sudah mirip dengan pemikiran teori hukum refleksif dimana suatu tatanan aturan yang ada di masyarakat yang dapat mencakup dan di terima oleh semua kalangan dan

${ }^{18}$ http://engkyndx.blogspot.co.id/2011/10/konsekuensi-yuridis-dari-kemajemukan.html, 02 November 2020, Pukul 03.34WIB 
lapisan masyarakat bangsa Indonesia. Jenis pendekatan hukum ke masyarakat yang mengedepankan dari pengendalian hukum itu sendiri sebagai pengganti dari pengambil alihan tanggungjawab pengaturan, demi hasil dari proses-proses sosial yang juga membatasi diri pada penempatan koreksi dan mendefinisikan ulang mekanisme-mekanisme pengaturan diri yang demokratis, Hukum atauaturan yang berfungsi sebagai sistem untuk melakukan koordinasi atas tindakan-tindakan dalam dan antara sub-sub sistem sosial yang semi otonom sebagai suatu proses transisi bangsa Indonesia.

\section{Penutup}

Berdasar dari penjabarkan pada pembahasan di atas, maka dapat disimpulkan bahwa pertama, dengan adanya tingkat kemajemukan yang tinggi di dalam masyarakat Indonesia ditengarai oleh: (a) kemajemukan kebudayaan, suku bangsa, adat istiadat dan kondisi geografis berpengaruh terhadap perkembangan hukum adat, yang kemudian bahwa dalam setiap pembuatan hukum di Indonesia (terutama aturan daerah) haruslah melihat keadaan atau kondisi masyarakat yang ada; (b) agama, bahwa mayoritas masyarakat Indonesia beragama Islam maka secara tidak langsung hal itu berpengaruh dalam setiap pembuatan aturan-aturan yang berlaku dalam masyarakat; (c) Penjajahan Bangsa Asing, dengan lamanya negara Indonesia dijajah bangsa asing maka hal tersebut membuat banyak sekali percampuran kebudayaan, yang salah satunya ialah adanya tata cara pemerintahan, kodifikasi hukum, dsb.

Kedua, prinsip-prinsip organisasional masyarakat (organizational principles of society) dan prinsip-prinsip yang timbul saling mempengaruhi proses-proses evolusioner di bidang sosial dan moral dalam masyarakat. Negara baik yang didasarkan atas teori kemasyarakatan maupun berdasarkan sejarah dan/atau hukum yang murni itu, satu sama lain tidaklah 'divergeren' atau bertentangan, melainkan saling isi mengisi, saling melengkapi, yakni bahwa pengertian Negara sebagai satu bentuk masyarakat yang memenuhi syarat tertentu tidak dapat mengabaikan unsur-unsur hukumnya.

\section{Daftar Pustaka}

\section{Buku}

Djojodigoeno, Asas-Asas Hukum Adat, Yayasan Badan Penerbit Gajah Mada, Yogyakarta, 1958.

Fajar, Mukti \& Yulianto Achmad, Dualisme Penelitian Hukum Normatif \& Empiris, Pustaka Pelajar, Yogyakarta, 2013. 
Koesno, Moh., Perkembangan Hukum Adat Setelah Perang Dunia II Dalam rangka Pembaharuan hukum Nasional, Dalam BPHN, Simposium Sejarah hukum, Binacipta, Bandung, 1976.

Marzuki, Peter Mahmud, Penelitian Hukum, Edisi Revisi, Kencana, Jakarta, 2011

Rambe, Ropaun \& A. Mukri Agafi, Implementasi Hukum Islam, PT Perca, Jakarta, 2001.

Soekanto, Soerjono, Kedudukan dan Peranan Hukum Adat Di Indonesia, Kurnia Esa Jakarta, 1982.

Sunggono, Bambang, Metode Penelitian Hukum, Cetakan ke 14, PT Grafindo Persada, Jakarta, 2013.

Van Dijk, R., Pengantar Hukum Adat Indonesia, Sumur, Bandung 1964.

Wisnubroto, Al., Quo Vadis Tatanan Hukum Indonesia, Universitas Atmajaya, Yogyakarta, 2007.

\section{Tesis}

Turnomo Rahardjo, Memahami Kemajemukan Masyarakat Indonesia (Perspektif Komunikasi Antarbudaya)", Tesis, Fakultas Hukum Universitas Diponegoro, Semarang, 2010.

\section{Artikel}

Majalah Kabare Jogja, edisi september 2014

SKH Kedaulatan Rakyat, 10 Agustus 2011

Turnomo Rahardjo, Makalah, Memahami Kemajemukan Masyarakat Indonesia (Perspektif Komunikasi Antarbudaya)

SKH Kedaulatan Rakyat, 10 Agustus 2011, hlm. 2

\section{Internet}

Febrinialdi's Blog, Analisa Kemajemukan Masyarakat Indonesia, 02 November 2020, Pukul 03.00 WIB

https:/ / www.slideshare.net/LestariMoerdijat/kemajemukan-masyarakatindonesia, diakses 02 November 2020, Pukul 01.00 WIB

https://indomaritim.id/keberagaman-dalam-masyarakat-indonesia/, diakses 02 November 2020. Pukul 01.30 WIB.

https:/ / www.kompasiana.com/elinrachma/5847c4f151f9fd1a0f70dcd6/faktorpenyebab-kemajemukan-di-indonesia?page=all , Artikel, Faktor Penyebab Kemajemukan Indonesia, 02 November 2020, Pukul 02.26

http://engkyndx.blogspot.co.id/2011/10/konsekuensi-yuridis-darikemajemukan.html, 02November 2020, Pukul03.34WIB

www.google.com, Artikel 20 Februari 2010, Kemajemukan Masyarakat Indonesia, 07 Maret 2018, Pukul 02.21 WIB 